\title{
Frequency of somatic MEN1 gene mutations in monoclonal parathyroid tumours of patients with primary hyperparathyroidism
}

\author{
S Miedlich ${ }^{1}, \mathrm{~K} \mathrm{Krohn}^{1}, \mathrm{P} \mathrm{Lamesch}^{2}$, A Müller ${ }^{3}$ and R Paschke ${ }^{1}$ \\ ${ }^{1}$ III Medical Department, ${ }^{2}$ II Department of Surgery and ${ }^{3}$ Institute of Pathology, University of Leipzig, Leipzig, Germany \\ (Correspondence should be addressed to R Paschke, III Medical Department, University of Leipzig, Philipp-Rosenthal Strasse 27, O4103 Leipzig, \\ Germany; Email: pasr@server3.medizin.uni-leipzig.de)
}

\begin{abstract}
Objectives: Investigation of small numbers of parathyroid tumours by X-chromosome inactivation analysis suggests that the majority of them are monoclonal lesions most likely caused by a somatic mutation. Somatic mutations in the MEN1 gene located on chromosome 11q13 have recently been identified in $12-17 \%$ of solitary parathyroid tumours in patients with sporadic primary hyperparathyroidism, and they may be the precipitating genetic defect leading to monoclonal cell proliferation in these tumours.

Design: To determine the prevalence of MEN1 gene mutations in monoclonal parathyroid neoplasias we investigated 33 parathyroid tumours of patients with primary hyperparathyroidism for clonality and mutations in the MEN1 gene.

Methods: X-chromosome inactivation analysis was used to assess the clonal status of the tumours, direct sequencing of the complete coding region was applied to identify mutations in the MEN1 gene. Results: Twenty-eight female patients ( 26 patients with solitary adenoma, 2 patients with hyperplasia) were informative for the polymorphism of the androgen receptor on the X-chromosome and could be tested for inactivation pattern. Nineteen of twenty-six (73\%) solitary adenomas were monoclonal. Somatic mutations in the MEN1 gene were identified in nine cases. Six of them were found in the relatively large second exon of the MEN1 gene (A49D, 193del36, 402delC, 482del22, 547delT, W126X). One was found in exon 5 (904del9), one in exon 7 (Y327X) and one in exon 9 (R415X). Of the monoclonal tumours, 5 out of 19 (26\%) harboured a somatic MEN1 gene mutation.

Conclusions: In summary, $73 \%$ of the solitary parathyroid adenomas were monoclonal. In $26 \%$ of the monoclonal tumours a somatic MEN1 gene mutation has been identifed. However, for $74 \%$ of monoclonal tumours of the parathyroids the underlying genetic defects are still not known.
\end{abstract}

European Journal of Endocrinology 143 47-54

\section{Introduction}

The molecular pathophysiology of parathyroid neoplasia is still incompletely understood. A solitary adenoma is found in $80-85 \%$ of the patients with primary hyperparathyroidism whereas multiglandular enlargement has been observed in $15-20 \%$ (1). It is widely accepted in tumour biology that neoplasms originate from a single cell with a somatic mutation conferring a growth advantage upon it and its progeny (2). To date, two genetic abnormalities have been identified in benign parathyroid tumours. In a small subset of parathyroid tumours, activation of the PRAD1 (parathyroid adenoma 1)/cyclin D1 oncogene has been found. It is caused by the rearrangement of the parathyroid hormone (PTH) promotor in proximity to the PRAD1 gene, a cell cycle regulator $(3,4)$. Moreover, somatic mutations of the MEN1 (multiple endocrine neoplasia type 1) gene located on chromosome 11q13 have recently been identified in $12-17 \%$ of solitary parathyroid tumours of patients with sporadic primary hyperparathyroidism (5-7). The finding that the tumours with somatic MEN1 gene mutations show allelic loss on 11q13 very likely indicates that they are monoclonal neoplasias. However, loss of heterozygosity $(\mathrm{LOH})$ on $11 \mathrm{q} 13$ in microdissected parathyroid tumours is not necessarily associated with a monoclonal pattern of X-chromosome inactivation analysis $(8,9)$, which suggests that LOH may not be a singular event.

$\mathrm{X}$-chromosome inactivation analysis is a different method to study clonality of neoplasias. It is based on the functional inactivation of one of the two X-chromosomes in all female somatic cells in early embryo genesis by DNA methylation at CpG sites (10). The established pattern of X-chromosome inactivation in one cell is passed on to its progeny. In a polyclonal tissue, random 
inactivation of paternal and maternal X-chromosomes can be found whereas monoclonal cell expansions show an identical pattern of inactivation of either the paternal or the maternal X-chromosome.

Two previous studies which investigated clonality of parathyroid tumours by X-chromosome inactivation analysis in 8 patients each indicate that the majority of the solitary adenomas are monoclonal lesions (11-13). However, the few tumours tested in these studies were only defined by histopathological rather than molecular criteria and somatic mutations were not determined. Therefore, the percentage of somatic mutations in the MEN1 gene in monoclonal parathyroid neoplasms is not known to date. Moreover, whereas clonality was previously found in 75 to $90 \%$ of solitary parathyroid tumours, LOH on 11q13 was only found in 27 to $39 \%$. These discrepant results raise the question whether the examined tumours with neither MEN1 gene mutations nor $\mathrm{LOH}$ on $11 \mathrm{q} 13$ are monoclonal neoplasias too. If so, this would imply that the majority of clonal cell expansions in the parathyroids are caused by other somatic mutations rather than the MEN1 gene mutations.

The intention of this study was, therefore, to test the hypothesis whether nearly all parathyroid tumours are monoclonal neoplasms and to answer the question as to what percentage MEN1 gene mutations can be found in monoclonal cell expansions. Evidence for clonality in a parathyroid tumour with a somatic mutation in the MEN1 gene would identify this somatic mutation as a likely precipitating genetic defect initiating the monoclonal cell expansion.

\section{Subjects and methods}

Thirty-three patients referred for parathyroidectomy for primary hyperparathyroidism in a consecutive series between April 1998 and February 1999 were included in the study. The morning before the operation, blood was collected for determination of total and ionized calcium, phosphate, creatinin and intact parathyroid hormone (IMMULITE Intact PTH Enzyme Immunometric Assay, DPC, Biomedical Analytics, $\mathrm{GmbH}$, Gottingen, Germany) as well as for extraction of leucocyte DNA. The intraoperative procedure included exploration of at least two parathyroid glands in the case of a solitary adenoma and all four glands in the case of more than one enlarged gland. Half of the enlarged gland was used for histopathological analysis and the other half was snap-frozen in liquid nitrogen and stored at $-80{ }^{\circ} \mathrm{C}$. The diagnosis of parathyroid adenoma or hyperplasia respectively was made by histological analysis. Criteria for a parathyroid adenoma are evidence of a capsule, almost complete absence of fat cells, and normal non-hyperplastic parathyroid tissue at the rim or in other removed parathyroid glands (14). According to these criteria, 31 patients had a solitary adenoma whereas in two cases parathyroid hyperplasia was diagnosed. All female patients with primary hyperparathyroidism were postmenopausal, three receiving hormone replacement therapy. None of them had clinical evidence of other endocrinopathies or a family history of other MEN1 manifestations. One patient was on haemodialysis for three years before kidney transplantation. However, she did not develop secondary but primary hyperparathyroidism which manifested shortly after kidney transplantation. Informed consent to participate in the study was obtained from all patients before surgery.

\section{X-chromosome inactivation analysis}

Frozen parathyroid tissue was mechanically disrupted and digested with proteinase K. Leucocyte DNA was extracted using the QIAamp blood kit (Qiagen, Chatsworth, CA, USA). X-chromosome inactivation analysis was repeated with microdissected paraffin-embedded parathyroid tissue for all tumours initially identified as polyclonal. For this purpose, microscopically identified hypercellular areas were circled on the glass slide. Tissue from the marked areas of three consecutive slides was microdissected and digested with proteinase $\mathrm{K}$ for extraction of DNA.

To determine random versus nonrandom X-chromosome inactivation we used a PCR approach described by Allen et al. (15). Conditions were the same as described by Krohn et al. (16). Briefly, amplification of a variable number of tandem repeats in the first exon of the androgen receptor (HUMARA) was studied after digestion with the methylation-sensitive restriction enzyme, HpaII. Two distinct PCR fragments are found in the case of heterozygosity for the tandem repeats. Nonrandom $\mathrm{X}$-chromosome inactivation results in one diminished allele after amplification of the digested DNA, and is suggestive of monoclonality. A polyclonal origin with random $\mathrm{X}$-chromosome inactivation would lead to reduction of both alleles. For detection of the PCR products, a 6-carboxy-fluorescein-labelled forward primer was used (Perkin Elmer Applied Biosystems, Foster City, CA, USA). PCR products were quantified on an ABI 373 Genetic Analyzer (Perkin Elmer Applied Biosystems) with the GeneScan software. The ratio of the numbers for the two alleles was calculated, and the ratio of the undigested DNA was divided by the ratio of HpaIIdigested DNA, according to Delabesse et al. (17). If necessary, the resulting number was inverted to give a ratio greater than 1 . The resulting index is close to 1 if the tissue is polyclonal. An index of 2 is more than two times the S.D. above the average index for a group of samples of polyclonal thyroid tissue (16) and was chosen as the lowest index indicating monoclonality.

\section{Sequencing}

One hundred nanograms extracted tumour DNA were amplified in a $50 \mu \mathrm{l}$ PCR. The reaction was carried out with the Prime Zyme PCR kit (Biometra, Diagnostic Prod. 
Table 1 List of the primer pairs used together with the annealing temperatures and the PCR product lengths.

\begin{tabular}{lllcc}
\hline Exon & \multicolumn{1}{c}{ Forward primer } & Reverse primer & $\begin{array}{c}\text { Annealing } \\
\text { temp. } \\
\left({ }^{\circ} \mathrm{C}\right)\end{array}$ & $\begin{array}{c}\text { Product } \\
\text { (base } \\
\text { pairs) }\end{array}$ \\
\hline $2-1$ & AACCTTAGCGGACCCTGG & ACGGGAAAGTAGGTGAGGC & 58 & 336 \\
$2-2$ & AACGTTCCCGAGCTCACCTTC & TAAGATTCCCACCTACTGGG & 58 & 304 \\
3 & ATCTGAGGTTGGGTCACAGG & AAATGGAGTCCCTTGGGTG & 59 & 401 \\
4 & ACATAATGATCTCATCCCCCC & CAGGCCAGGAATTACTAACCC & 60 & 289 \\
$5 / 6$ & GTTAGTAATTCCTGGCCTGGC & TGCCTCAGCCACTGTTAGG & 60 & 479 \\
7 & CTGAGGATCCTCTGCCTCAC & GATGGAGGGGAAGAAAGGC & 60 & 218 \\
8 & TTCAGACCCTACAGAGACCCC & GCCCAGGACCTCAGTTATAGC & 59 & 330 \\
9 & CTTACCTTTCTGGAGCCAGG & ACCACCTGTAGTGCCCAGAC & 60 & 317 \\
$10-1$ & AACCTTGCTCTCACCTTGCTCT & AGCGACAGTCCCAGGAGGCTT & 58 & 255 \\
$10-2$ & CAGGGTGCAGTGTCAGGA & CCCACAAGCGGTCCGAAGTCC & 58 & 341 \\
\hline
\end{tabular}

Corp., Los Angeles, CA, USA) and $500 \mathrm{nmol} / \mathrm{l}$ of forward and reverse primer. Ten primer pairs were used to amplify exon 2 to 10 of the MEN1 gene (Table 1). PCR conditions were as follows: initial denaturation at $95^{\circ} \mathrm{C}$ for $5 \mathrm{~min}, 35 \mathrm{cycles}$ at $95^{\circ} \mathrm{C}$ for $30 \mathrm{~s}, 58-60^{\circ} \mathrm{C}$ for $30 \mathrm{~s}$, $72{ }^{\circ} \mathrm{C}$ for $1 \mathrm{~min}$ and a final extension of $72{ }^{\circ} \mathrm{C}$ for $10 \mathrm{~min}$.

Approximately $50 \mathrm{ng}$ of the PCR product were used for direct sequencing with the Applied Biosystems PRISM dye terminator cycle sequencing ready reaction kit (Perkin Elmer, Applied Biosystems). If a sequence variation was detected, PCR and sequencing reaction were repeated with the tumour tissue and the corresponding leucocyte DNA for confirmation and evaluation of somatic versus germline origin of the genetic variation.

\section{Statistical analysis}

All statistical analyses were carried out with the statistical package PRISM, version 2.01 (GraphPad Software Inc., San Diego, CA, USA). Comparison of the clinical parameters between patients with or without somatic MEN1 gene mutations with monoclonal or polyclonal tumours and between patients with a parathyroid adenoma or hyperplasia was carried out by unpaired $t$-tests. A $P$ value $<0.05$ was considered as significant.

\section{Results}

\section{Analysis of the clinical data}

Mean age of the 33 patients with primary hyperparathyroidism was $62 \pm 9$ years, mean values $( \pm$ standard deviation) of serum total calcium were $2.98 \pm$ $0.22 \mathrm{mmol} / \mathrm{l}$ (normal range: $2.02-2.60 \mathrm{mmol} / \mathrm{l}$ ), of ionized calcium $1.59 \pm 0.16 \mathrm{mmol} / \mathrm{l}$ (normal range: $1.12-1.23 \mathrm{mmol} / \mathrm{l}$ ), of phosphate $0.77 \pm 0.14 \mathrm{mmol} / \mathrm{l}$ (normal range: $0.84-1.45 \mathrm{mmol} / \mathrm{l}$ ), of intact parathyroid hormone $150 \pm 63 \mathrm{pg} / \mathrm{ml}$ (normal range: 10$65 \mathrm{pg} / \mathrm{ml}$ ) and of creatinin $93 \pm 19 \mu \mathrm{mol} / \mathrm{l}$ (normal range: female $44-80 \mu \mathrm{mol} / \mathrm{l}$, male $53-97 \mu \mathrm{mol} / \mathrm{l}$ ).

Comparison of the clinical and biochemical parameters (age, serum total and ionized calcium, phosphate, creatinin and parathyroid hormone levels) revealed no significant differences between patients with or without MEN1 gene mutations and polyclonal or monoclonal tumours ( $P$ values between 0.06 and 0.9 , see Table 2).

\section{X-chromosome inactivation analysis}

$\mathrm{X}$-chromosome inactivation was assessed for tumour tissue of 31 women ( 29 with a solitary adenoma, 2 with hyperplasia). Twenty-eight subjects $(90 \%)$ were heterozygous for the (CAG)n-polymorphism on exon 1 of the

Table 2 Clinical data of the patients (age, serum total calcium (Ca total, normal range: $2.02-2.60 \mathrm{mmol} / \mathrm{l})$, ionized calcium (Ca ion, normal range: $1.12-1.23 \mathrm{mmol} / \mathrm{l})$, phosphate $\left(\mathrm{PO}_{4}\right.$, normal range: $\left.0.84-1.45 \mathrm{mmol} / \mathrm{l}\right)$, $\mathrm{PTH}$ (normal range: $\left.10-65 \mathrm{pg} / \mathrm{ml}\right)$, and $\mathrm{creatinin}(\mathrm{normal}$ range: female $44-80 \mu \mathrm{mol} / \mathrm{l}$, male 53-97 $\mu \mathrm{mol} / \mathrm{l}$ ) levels) expressed as means \pm S.D. Comparison of patients with parathyroid adenomas or hyperplasia, with or without MEN1 gene mutations, and with polyclonal or monoclonal parathyroid tumours. Differences were not statistically significant.

\begin{tabular}{|c|c|c|c|c|c|c|}
\hline & $\begin{array}{c}\text { Age } \\
\text { (years) }\end{array}$ & $\begin{array}{l}\text { Ca total } \\
(\mathrm{mmol} / \mathrm{l})\end{array}$ & $\begin{array}{l}\text { Ca ion } \\
(\mathrm{mmol} / \mathrm{l})\end{array}$ & $\begin{array}{c}\mathbf{P O}_{4} \\
(\mathrm{mmol} / \mathrm{l})\end{array}$ & $\begin{array}{c}\text { PTH } \\
(\mathrm{pg} / \mathrm{ml})\end{array}$ & $\begin{array}{c}\text { Creatinin } \\
(\mu \mathrm{mol} / \mathrm{l})\end{array}$ \\
\hline Adenoma $(n=31)$ & $61 \pm 9$ & $2.98 \pm 0.22$ & $1.59 \pm 0.16$ & $0.77 \pm 0.14$ & $174 \pm 146$ & $92 \pm 20$ \\
\hline Hyperplasia $(n=2)$ & $68 \pm 13^{*}$ & $2.95 \pm 0.2^{*}$ & $1.58 \pm 0.25^{\star}$ & $0.75 \pm 0.12^{*}$ & $211 \pm 50^{*}$ & $99 \pm 14^{*}$ \\
\hline Mutation $(n=9)$ & $61 \pm 10$ & $2.91 \pm 0.19$ & $1.52 \pm 0.13$ & $0.78 \pm 0.18$ & $119 \pm 47$ & $86 \pm 11$ \\
\hline No mutation $(n=24)$ & $61 \pm 9$ & $2.99 \pm 0.22$ & $1.59 \pm 0.11$ & $0.76 \pm 0.12$ & $167 \pm 65$ & $94 \pm 20$ \\
\hline Monoclonal $(n=19)^{\prime}$ & $61 \pm 10$ & $2.96 \pm 0.24$ & $1.60 \pm 0.18$ & $0.82 \pm 0.12$ & $181 \pm 163$ & $90 \pm 20$ \\
\hline Polyclonal $(n=9)$ & $63 \pm 11$ & $3.02 \pm 0.1$ & $1.65 \pm 0.11$ & $0.66 \pm 0.1$ & $258 \pm 65$ & $89 \pm 15$ \\
\hline
\end{tabular}

\footnotetext{
${ }^{*}$ No $t$-test due to low number.
} 
Table 3 MEN1 gene mutations and clonality of examined parathyroid tumours. An index $<2$ indicates polyclonal origin, an index $\geq 2$ indicates monoclonality.

\begin{tabular}{|c|c|c|c|c|}
\hline Case No. & Sex & Index & Clonality & Mutation \\
\hline \multicolumn{5}{|c|}{ Solitary adenomas } \\
\hline 1 & Male & n.st. & & 547delT \\
\hline 2 & Male & n.st. & & n.d. \\
\hline 7 & Female & n.i. & & A49D \\
\hline 20 & Female & n.i. & & 193del36 \\
\hline 23 & Female & n.i. & & n.d. \\
\hline 4 & Female & 2.42 & Monoclonal & n.d. \\
\hline 6 & Female & 2.70 & Monoclonal & n.d. \\
\hline 9 & Female & 2.58 & Monoclonal & n.d. \\
\hline 10 & Female & 5.99 & Monoclonal & W126X \\
\hline 11 & Female & 6.03 & Monoclonal & n.d. \\
\hline 12 & Female & 2.43 & Monoclonal & n.d. \\
\hline 14 & Female & 3.65 & Monoclonal & n.d. \\
\hline 16 & Female & 13.87 & Monoclonal & n.d. \\
\hline 19 & Female & 4.09 & Monoclonal & n.d. \\
\hline 21 & Female & 2.43 & Monoclonal & n.d. \\
\hline 24 & Female & 2.82 & Monoclonal & n.d. \\
\hline 25 & Female & 9.27 & Monoclonal & 402delC \\
\hline 26 & Female & 4.93 & Monoclonal & n.d. \\
\hline 27 & Female & 2.44 & Monoclonal & n.d. \\
\hline 28 & Female & 4.17 & Monoclonal & n.d. \\
\hline 29 & Female & 11.07 & Monoclonal & n.d. \\
\hline 30 & Female & 2.34 & Monoclonal & 904del9 \\
\hline 32 & Female & 2.56 & Monoclonal & 482del22 \\
\hline 35 & Female & 3.23 & Monoclonal & $\mathrm{R} 415 \mathrm{X}$ \\
\hline 5 & Female & 1.49 & Polyclonal & Y327X \\
\hline 15 & Female & 1.53 & Polyclonal & n.d. \\
\hline 31 & Female & 1.33 & Polyclonal & n.d. \\
\hline 33 & Female & 1.32 & Polyclonal & n.d. \\
\hline 34 & Female & 1.50 & Polyclonal & n.d. \\
\hline 36 & Female & 1.43 & Polyclonal & n.d. \\
\hline 37 & Female & 1.27 & Polyclonal & n.d. \\
\hline \multicolumn{5}{|c|}{ Hyperplasia } \\
\hline 3 & Female & 1.44 & Polyclonal & n.d. \\
\hline 18 & Female & 1.21 & Polyclonal & n.d. \\
\hline
\end{tabular}

n.d., mutation not detected; n.st., not studied due to male sex; n.i., not informative due to homozygosity.

androgen receptor. Three patients with a solitary parathyroid tumour were not informative for the polymorphism. Nineteen of twenty-six solitary adenomas (73\%) showed nonrandom X-chromosome inactivation. In one of the 19 tumours nonrandom X-chromosome inactivation could only be identified after repetition of the analysis with microdissected paraffin-embedded tissue following histological examination. The two cases with parathyroid hyperplasia showed random inactivation (Table 3). Examples of one random and non-random X-chromosome inactivation pattern, respectively, are shown in Fig. 1.

\section{Analysis of the MEN1 gene}

Mutational analysis revealed alterations in the MEN1 gene in 14 of 33 examined parathyroid tumours. Two variations were found within intronic sequences $(2249 \mathrm{C} / \mathrm{G}, 5146 \mathrm{G} / \mathrm{A})$. They were both present in tumour and leucocyte DNA. $2249 \mathrm{C} / \mathrm{G}$ is located 39 base pairs upstream of the start codon. It was identified in three patients and is most likely a polymorphism. $5146 \mathrm{G} / \mathrm{A}$ is located 31 base pairs upstream of exon 5 . As the patient ( 58 years old) with this germline genetic variation had neither a history nor clinical symptoms of other endocrinopathies suggestive of MEN1 it seems unlikely that this genetic variation represents an intronic mutation of putative splice sites leading to a MEN1 phenotype. Furthermore, $80 \%$ of the patients with MEN1 show symptoms before the age of 50 (18). However, it cannot be excluded completely that this patient suffers from a sporadic form of MEN1 with a parathyroid adenoma as the only manifestation. Three polymorphisms were found in exons 3,9 and 10 (R171Q, D418D, K588K). R171Q and D418D are polymorphisms which have previously been reported in healthy subjects with frequencies of $1.4 \%$ and $42 \%$ respectively (19). The silent polymorphism K588K (AAG588AAA) was found in one of the examined cases and has not been reported before. As described for 
Random X-chromosome inactivation (case no.18)
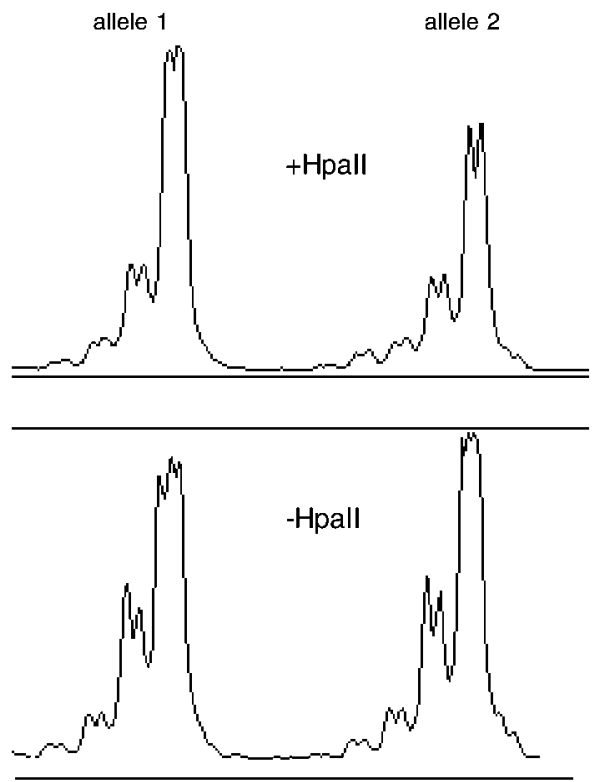

Non-random X-chromosome inactivation (case no. 10)
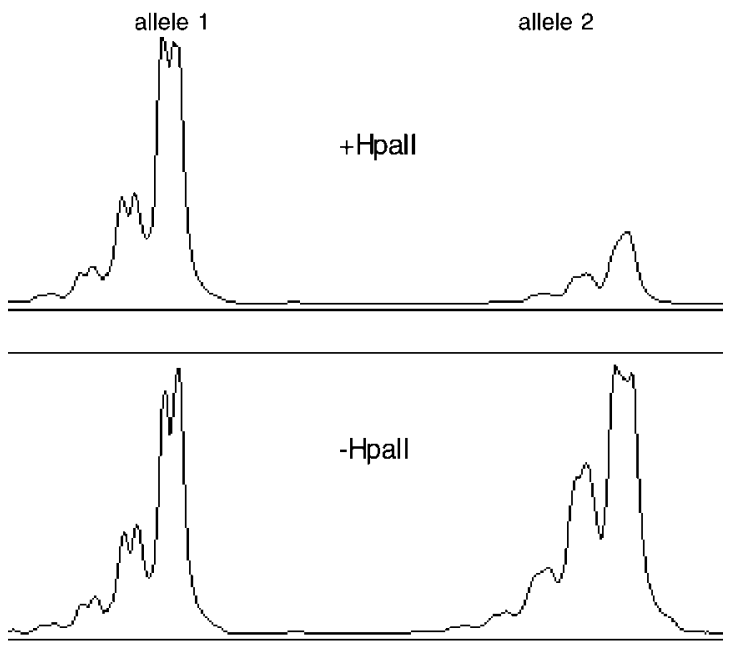

Figure 1 Separation of fluorescence-labelled PCR products from exon 1 of the androgen receptor gene. Amplified DNA from tumorous parathyroid tissue of two cases with $(+\mathrm{Hpall})$ and without (-Hpall) addition of Hpall is shown. PCR products of the two alleles are indicated as allele 1 and 2. Loss of PCR amplification of one allele in the tumour suggests monoclonal origin. Upper panel: case no. 18 (patient with primary hyperparathyroidism due to parathyroid hyperplasia). Lower panel: case no. 10 (patient with primary hyperparathyroidism due to an adenoma).

5146G/A, it may be possible that this germline genetic variation results in an aberrant splicing of the tumour RNA. However, this patient, aged 57 years, showed no other MEN1 manifestation making a sporadic MEN1 variant relatively unlikely.

Mutations in the MEN1 gene were detected in nine cases. Six of them were found in the relatively large second exon of the MEN1 gene (A49D, 193del36, 402delC, 482del22, 547delT, W126X). One was found in exon 5 (904del9), one in exon 7 (Y327X, Fig. 2) and one in exon 9 (R415X). Mutations 193 del36 (Fig. 2) and 904 del 9 are in-frame deletion mutations leading to deletion of 12 and 3 amino acids respectively. Mutations 402 delC, 482 del 22 and 547 delT are frame-shift deletions which result in altered amino acid sequences and creation of stop codons after 20, 52 and 38 triplets respectively. The deletions and the nonsense mutations (W126X, Y327X, R415X) lead to early truncation of the protein product. One mutation results in an alteration of the amino acid sequence (A49D). In seven of nine sequences with MEN1 gene mutations, the peaks of the mutated sequence are higher than the wildtype sequence peaks. None of the mutations were found in the corresponding leucocyte DNA and are therefore somatic mutations. Five tumours with a somatic MEN1 gene mutation could be identified as monoclonal lesions. One tumour with a somatic MEN1 gene mutation was polyclonal. Two were not informative for the polymorphism of the androgen receptor, one was a male patient. All patients with somatic mutations in the MEN1 gene suffered from primary hyperparathyroidism due to solitary adenomas.

\section{Discussion}

It is widely accepted that somatic mutations of protooncogenes or tumour suppressor genes initiate clonal cell expansion. The intention of this study was to test whether nearly all parathyroid neoplasms are monoclonal lesions and to define the role of the recently described mutations in the MEN1 gene for monoclonal parathyroid neoplasias in the setting of primary hyperparathyroidism.

In this study, $73 \%$ of the patients with primary hyperparathyroidism due to a solitary adenoma harboured a monoclonal tumour. Twenty-six percent of the monoclonal parathyroid tumours and $30 \%$ of all tested tumours had somatic mutations in the MEN1 gene. Recent studies reported MEN1 gene mutations in 12$17 \%$ of solitary parathyroid adenomas (5-7). The methods used for mutational screening were dideoxyfingerprinting, single strand conformation analysis and direct sequencing. The higher percentage reported in our study could be due to different sensitivities of the methods used. For dideoxyfingerprinting variable sensitivities have been reported (20). Single strand conformation analysis is known to be less sensitive than direct sequencing (21). The study using direct sequencing found somatic MEN1 gene mutations in $13 \%$ of solitary parathyroid tumours (7). However, the authors only sequenced the exons $2-10$ of the MEN1 gene if $\mathrm{LOH}$ on $11 \mathrm{q} 13$ was detected. $\mathrm{LOH}$ analysis was performed using three microsatellite markers at chromosome $11 q 13$ (PYGM, INT-2 and D11S906) spanning a relatively large area of at least $1.2 \mathrm{Mb}(22)$. Therefore, 


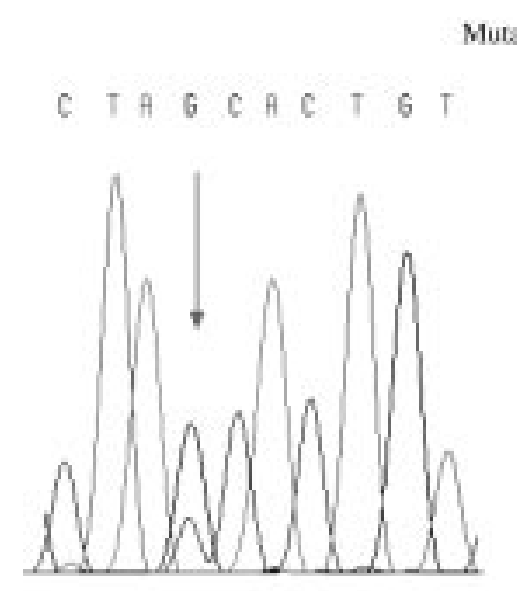

DNA extracted from tumour

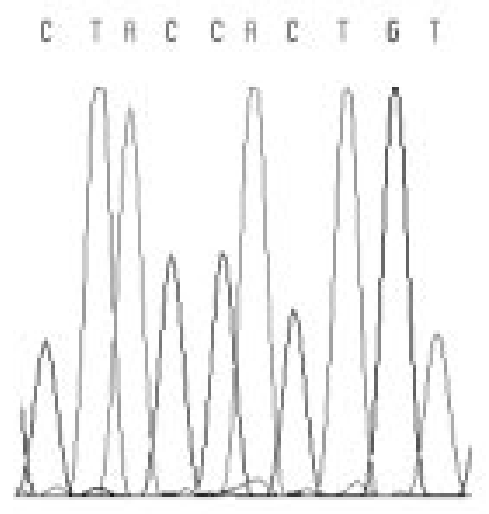

DNA extracted from leucocytes

Mutation 193del36

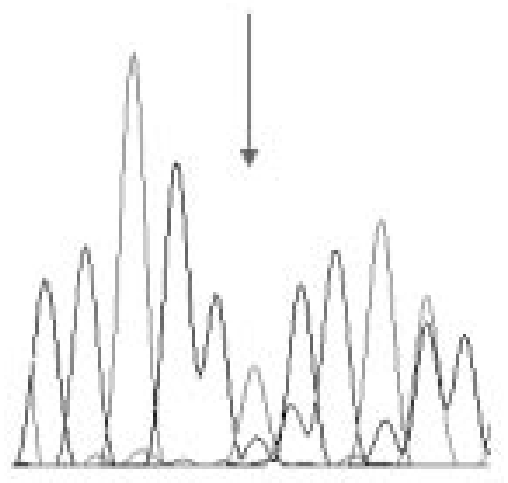

DNA exiracted from tumour

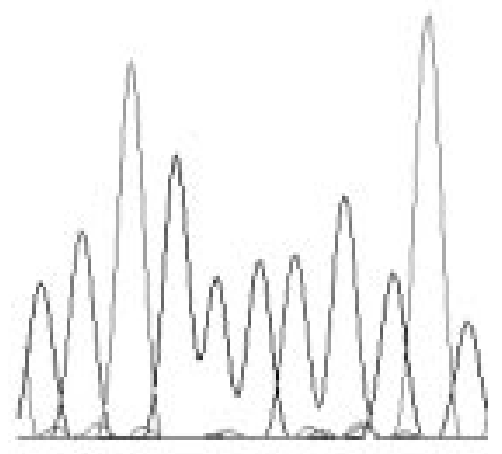

DNA extracted from leucocytes
Figure 2 Sequencing data of exon 7 and exon 2 of the MEN1 gene, amplified from parathyroid tumours of two patients with primary hyperparathyroidism. Mutations, marked by an arrow (Y327X - case no. 5, upper panel; 193del36 - case no. 20, lower panel) were detected in tumour tissue but not in the corresponding DNA extracted from peripheral leucocytes, and are therefore somatic mutations. this study could have missed tumours with somatic MEN1 gene mutations and very small allelic deletions on 11q13 not detected with the above mentioned technique. Our results suggest that somatic mutations in the MEN1 gene occur more frequently in solitary parathyroid adenomas than previously reported.

Nevertheless, $74 \%$ of the identified monoclonal tumours did not have mutations in the MEN1 gene. Therefore, other somatic mutations are likely to play a role in the clonal cell expansions in the parathyroids of patients with primary hyperparathyroidism. Rearrangement of the PRAD1 oncogene may be responsible for a small subset of tumours $(11,23,24)$. However, for the majority of parathyroid adenomas the underlying genetic defects are still waiting to be identified. Allelotyping studies of parathyroid neoplasias describe allelic losses on chromosomes 1p, 1q, 6q, 9p, 9q, 11p,
$11 q, 13 q$ and $15 q$ and less frequently allelic gains on chromosomes 1q, 5q, 16p and 19p (25). These findings strongly suggest the activation or inactivation of other, at present unknown, oncogenes or tumour suppressor genes respectively. Moreover, the variety of chromosomal abnormalities suggests heterogeneous genetic defects leading to parathyroid neoplasms.

In this study, $27 \%$ of the tumours tested for clonality showed a polyclonal pattern. X-chromosome inactivation can give false polyclonal results because of contamination with normal tissue. To minimize contamination by polyclonal tissue, we repeated X-chromosome inactivation analysis for solitary adenomas showing random $\mathrm{X}$-chromosome inactivation in snap-frozen tissue using microdissected paraffin-embedded material clearly identified as adenomatous parathyroid tissue. Using this technique one of the previously polyclonal samples 
showed a monoclonal inactivation pattern. Seven solitary tumours repeatedly gave ratios suggesting a polyclonal origin. Besides admixture with normal tissue, a pattern suggestive of a polyclonal origin could also result from an aberrant pattern of DNA methylation or the presence of two clonal expansions with opposing $\mathrm{X}$-chromosome inactivation patterns (12). Furthermore, a comparison of two independent methods for the study of X-chromosome inactivation reported conflicting results in $10 \%$ of all cases evaluated (15). In summary, the results of X-chromosome inactivation analysis allow the conclusion that the majority of solitary parathyroid tumours evolve from single cells.

Regarding the MEN1 gene mutations, $85 \%$ of the mutations reported in previous studies are inactivating (26). Furthermore, other authors report loss of heterozygosity on chromosome 11q13 (the location of the MEN1 gene) in parathyroid tumours with MEN1 gene mutations (5-7). Therefore, it has been assumed that menin acts as a tumour suppressor. According to Knudson's hypothesis (27), inactivation of a tumour suppressor only occurs after mutation in one allele and loss of the wildtype allele. Looking at our sequencing data, it must be stated that the peaks of the mutated sequences are nearly always higher than the wildtype sequence peaks. In contrast, sequencing data of DNA from thyroid tumours with somatic heterozygous mutations of the thyrotrophin receptor nearly always give peaks for the mutated allele which are less than $50 \%$ of the wildtype sequence peaks (28). This is due to the fact that direct sequencing requires a distribution of mutated and wildtype alleles close to $1: 1$. As tumour tissue can be contaminated with fibroblasts or blood cells this will further reduce the frequency of the mutated alleles. Thus, it can be difficult to distinguish a small mutated peak from an unspecific background. In the case of a hemizygous mutation, which is assumed for MEN1 gene mutations, dominance of the mutated allele can be expected, as the wildtype allele has been lost. Therefore, the mutations with the mutated peak higher than the wildtype peak are strongly suggestive of hemizygosity. Moreover, $90 \%$ of the mutations we found are nonsense mutations (W126X, Y327X, R415X) and deletions (193del36, 402delC, 482del22, 547delT, 904del9) leading to truncation and subsequent inactivation of the protein. In summary, our results are in line with the assumed function of the MEN1 gene product as a tumour suppressor. New mutations in this large gene that can be inactivated throughout its reading frame are being found continuously. In this study, seven of nine mutations we describe (A49D, 193del36, 402delC, 482del22, 547delT, 904del9 and Y327X) have not been reported before.

The clinical characteristics of the patients with or without MEN1 gene mutations in the parathyroid tumours were not different. Therefore, it cannot be concluded that mutations in the MEN1 gene lead to a specific phenotype of very mild or very severe primary hyperparathyroidism. This result confirms other reports which compared the clinical characteristics of patients with or without LOH on $11 \mathrm{q} 13$ and with or without MEN1 gene mutations (6, 7). Furthermore, the presence of MEN1 gene mutations in parathyroid tumours of patients with very mild forms of primary hyperparathyroidism found by Carling et al. (7) indicates that loss of function of this putative tumour suppressor is not necessarily associated with an excessive tumour growth.

\section{References}

1 Silverberg SJ \& Bilezikian JP. Primary hyperparathyroidism: still evolving? Journal of Bone and Mineral Research 199712 856-862.

2 Knudson AGJ. Mutation and cancer in man. Cancer 197739 (Suppl 4) 1882-1886.

3 Arnold A, Kim HG, Gaz RD, Eddy RL, Fukushima Y, Byers MG et al. Molecular cloning and chromosomal mapping of DNA rearranged with the parathyroid hormone gene in a parathyroid adenoma. Journal of Clinical Investigation $1989832034-2037$.

4 Rosenberg CL, Kim HG, Shows TB, Kronenberg HM \& Arnold A. Rearrangement and overexpression of D11S287E, a candidate onco gene on chromosome 11q13 in benign parathyroid tumors. Oncogene $19996449-453$.

5 Heppner C, Kester MB, Agarwal SK, Debelenko LV, EmmertBuck MR, Guru SC et al. Somatic mutation of the MEN1 gene in parathyroid tumours. Nature Genetics 199716 375378.

6 Farnebo F, Teh BT, Kytola S, Svensson A, Phelan C, Sandelin K et al. Alterations of the MEN1 gene in sporadic parathyroid tumors. Journal of Clinical Endocrinology and Metabolism 199883 2627-2630.

7 Carling T, Correa P, Hessman O, Hedberg J, Skogseid B, Lindberg D et al. Parathyroid MEN1 gene mutations in relation to clinical characteristics of nonfamilial primary hyperparathyroidism. Journal of Clinical Endocrinology and Metabolism 199883 29602963.

8 Morelli A, Falchetti A, Amorosi A, Tonelli F, Bearzi T, Ranaldi R et al. Clonal analysis by chromosome 11 microsatellite-PCR of microdissected parathyroid tumors from MEN1 patients. Biochemical and Biophysical Research Communications 1996227 736742 .

9 Lubensky IA, Zhuang Z, Emmert-Buck MR, Dong Q, Guru SC, Manickam $\mathrm{P}$ et al. Allelic deletions on chromosome $11 \mathrm{q} 13$ in multiple tumors from individual MEN1 patients. Cancer Research $1996565272-5278$.

10 Lyon MF. X-chromosome inactivation, and developmental patterns in mammals. Biological Review 197247 1-35.

11 Arnold A, Staunton CE, Kim HG, Gaz RD \& Kronenberg HM. Monoclonality and abnormal parathyroid hormone genes in parathyroid adenomas. New England Journal of Medicine 1988318 658-662.

12 Arnold A, Brown MF, Urena P, Gaz RD, Sarfati E \& Drueke TB. Monoclonality of parathyroid tumors in chronic renal failure in parathyroid hyperplasia. Journal of Clinical Investigation 199595 2047-2053.

13 Shan L, Nakamura M, Nakamura Y, Inoue D, Morimoto S, Yokoi T et al. Comparative analysis of clonality and pathology in primary and secondary hyperparathyroidism. Virchows Archiv 1997430 247-251.

14 Black WC III \& Utley JR. The differential diagnosis of parathyroid adenoma and chief cell hyperplasia. American Journal of Clinical Pathology $196849761-775$.

15 Allen RC, Zoghbi HY, Moseley AB, Rosenblatt HM \& Belmont JW. Methylation of HpaII and HpaI sites near the polymorphic CAG repeat in the human androgen-receptor correlates with $\mathrm{X}$ 
chromosome inactivation. American Journal of Human Genetics 199251 1229-1239.

16 Krohn K, Fuehrer D, Holzapfel HP \& Paschke R. Clonal origin of toxic thyroid nodules with constitutively activating thyrotropin receptor mutations. Journal of Clinical Endocrinology and Metabolism 199883 130-134.

17 Delabesse E, Aral S, Kamoun P, Varet B \& Turhan AG. Ouantitative non-radioactive clonality analysis of human leucemic cells and progenitors using the human androgen receptor (ar) gene. Leukemia 19959 1578-1582.

18 Trump D, Farren B, Wooding C, Pang JT, Besser GM, Buchanan KD et al. Clinical studies of multiple endocrine neoplasia type 1 (MEN1). Quarterly Journal of Medicine 199689653 669.

19 Chandrasekharappa SC, Guru SC, Manickam P, Olufemi SE, Collins FS, Emmert-Buck MR et al. Positional cloning of the gene for multiple endocrine neoplasia-type 1. Science $1997276404-$ 407.

20 Liu Q \& Sommer SS. Parameters affecting the sensitivities of dideoxyfinger-printing and SSCP. PCR Methods and Applications 19944 97-108.

21 Prosser J. Detecting single base mutations. Trends in Biotechnology $199311238-246$.

22 Agarwal SK, Debelenko LV, Kester MB, Guru SC, Manickam P, Olufemi SE et al. Analysis of recurrent germline mutations in the MEN1 gene encountered in apparently unrelated families. Human Mutation 199812 75-82.
23 Friedman E, Bale AE, Marx SJ, Norton JA, Arnold A, Tu T et al. Genetic abnormalities in sporadic parathyroid adenomas. Journal of Clinical Endocrinology and Metabolism 199017 293-297.

24 Hsi ED, Zukerberg LR, Yang W-I \& Arnold A. Cyclin D1/PRAD1 expression in parathyroid adenomas: an immunohistochemical study. Journal of Clinical Endocrinology and Metabolism 199681 1736-1739.

25 Palanisamy N, Imanishi Y, Rao PH, Chaganti RSK \& Arnold A. Novel chromosomal abnormalities identified by comparative genomic hybridisation in parathyroid adenomas. Journal of Clinical Endocrinology and Metabolism 199883 1766-1770.

26 Thakker RV. Multiple endocrine neoplasia syndromes of the twentieth century. Journal of Clinical Endocrinology and Metabolism $1998832617-2620$.

27 Knudson AG Jr. Mutation and cancer: statistical study of retinoblastoma. Proceedings of the National Academy of Sciences of the USA $197168820-823$.

28 Fuehrer D, Holzapfel HP, Wonerow P, Scherbaum WA \& Paschke R. Somatic mutations in the thyrotropin receptor gene and not in the Gs alpha protein gene in 31 toxic thyroid nodules. Journal of Clinical Endocrinology and Metabolism 1997 82 3885-3891.

Received 21 October 1999

Accepted 24 February 2000 